\title{
Educational program in field hockey for beginners according to the kinematic comparison between straight vertical hit and hitting the ball with the flat-face ball *A.Prof.Dr/ Amal Anwar AbdeLsaLam ** Dr. Samar Hassan Ahmed Manai
}

Introduction and research problem:

The skill of the straight vertical strike despite the ease of its performance during the movement, but it is still an important strike that players must use during difficult play conditions, which require using the greatest muscle ability of the player to perform this skill with the required speed and accuracy. (4: 24)

Hitting the ball with the flat face of the stick is to send the ball for a long distance, as to be strong and fast in its movement, what distinguishes this strike that it is difficult to repel and can be performed from a stable or moving position and it uses the arms and trunk to give strength to the ball,it is used in long passes, aiming on targets, perform free kicks, and change the direction of the pitch. (5:109), (7: 89)

racket sports in general, did not receive much attention in terms of identifying the characteristics causing skill performance so that they can be used in the development of players performance, where it is necessary to recognize the motor characteristics of racket skills, to reach the basic mechanisms used in the performance of these skills in racket sports (8:717), one of the most important objectives of biomechanics is to develop and improve sports performance, through descriptive performance analysis $(16: 28,29)$

The researchers noted some technical errors associated with the performance of the skill of hitting the ball with the flat

Assistant Professor at Department of games Faculty of Physical Education for Girls Zagazig University.

"Lecturer at Department of games Faculty of Physical Education for Girls Zagazig University. 
face, where the students of the first division perform the skill of the straight vertical strike instead when shooting at the goal at the end of the applied exam model although the decision of the first division course does not contain Straight vertical stroke skill and is not taught to female students, which called the researchers to use the threedimensional kinematic analysis of the kinematic indicators of the two skills to extract the most indicators that contribute to the performance of the skills and to detect errors and then modify and evaluate the technique according to the kinematic indicators derived from outstanding female students in skill performance under research and using These indicators to teach the students of the first division to raise their performance level or the skill of hitting the ball with the flat face and differentiate between them and the skill of the straight vertical strike and do not confuse them, so the researchers conducted this study which is a kinematic comparison between the straight vertical blow and the hitting The ball with the flat face as the basis for the development of an educational program for beginners in field hockey in order to identify the contribution ratios of the kinematic

characteristics of the performance of the skills of the straight vertical strike and hitting the ball with the flat face in the field hockey to extract the most important kinamatic characteristics which can Help in learning the correct technical performance of the skills as well as identifying the differences between the variables most related to the skills in question and the level of performance accuracy.

\section{The aim of the research is:}

The research aims to make An Educational program according to kinematic comparison between a straight vertical hit and hitting the ball with the flat-face as the basis for developing an educational program for beginners in field hockey.

\section{Research questions:}

1- Is there a correlation between the kinematic indicators of straight vertical strike skills and hitting the ball with the flat face during both backward swinging and beating 
moments and performance accuracy level?

2- Can it be possible to identify the contribution ratios of the kinematic indicators of the two straight vertical strike skills and hitting the ball at the level of performance accuracy during both backward swinging and beating moments?

3- Are there statistically significant differences between the most dynamic indicators associated with straight vertical strike skills and hitting the ball with the flat face at the level of performance accuracy?

4- Are there statistically significant differences between the pre and post measurements of the experimental group in the post measurement of the skill of hitting the ball with the flat face of the students of the first division of the Faculty of Physical Education for Girls, Zagazig University?

\section{Research procedures: \\ Research methodology:}

The researchers used the pre and post measurement experimental method for a single experimental group and 3D kinamatic analysis using five high-speed cameras and the Simi Motion Analyses computer program
Research community:

the first group (racket games) at the Faculty of Physical Education girls of Zagazig University, for the academic year 2017/2018, and the number of (856) students.

Research Sample (standard):

Represented by (7) players of the Zagazig University team for field hockey due to their excellence in the skills of the straight vertical strike and hitting the ball with the flat face in field hockey, and each player performed (3) attempts for each skill of skills in question, and was chosen the best attempt for each player according to The accuracy of the pass, to become the number of attempts analyzed and subjected to statistical analysis (7) tries to the skill of the straight vertical blow, (7) tries to the skill of hitting the ball, attachment (6) presents images of the Research procedures.

\section{Basic Research sample:}

The two researchers selected (20) students to use it as an experimental group whom applied the educational program for the skill of hitting the ball with the flat face using the kinamatic indicators extracted, then the researchers 
selected

(12) students randomly to conduct the surveys for research, thus the research sample becomes (32) students.

\section{Homogeneity of Research sample:}

The researchers found homogeneity of the model sample, where the distortion coefficients in the variables age (years) height $(\mathrm{cm})$ weight $(\mathrm{kg})$ training age between $(-0.364)$ and (1.161) i.e. between +3 , indicating the moderation of data distribution, the researchers conducted homogenization of the total research sample (Basic and reconnaissance) where the distortion coefficients in the variables age (years) height $(\mathrm{cm})$ weight $(\mathrm{kg})$ between ($0.364)$ and (1.161) i.e. between +3 , indicating the moderation of data distribution.

Motor analysis devices and tools:

Advanced computer module, Simi Motion Analysis program, (1) calibration box (1m x $1 \mathrm{~m} \times 1 \mathrm{~m}) 3 \mathrm{D}$ Calibration, (5) high-speed video camera from 50 to 250 frames/s type Gpro, (5) memory card capacity (132) Gb Brand San
Disk, (5) tripod Equipped with a water scale.

\section{Skill tests:}

- Test the accuracy of the straight vertical stroke.

- Test the accuracy of hitting the ball with the flat face.

\section{Determination the stages of} performance that will be studied:

- The moment of backward swinging, which is the moment of the beginning of the movement of the wrist of the holding the hand of the racket during it's return from the front swing till the end of the swinging moment and before the moment of collision and beating .

- The moment of collision and beating, which is the moment when the bat meets with the ball.

Survey study of the standard model:

It was conducted on Sunday, 11/2/2018, to $14 / 2 / 2018$ and reached the sample of the survey was (3) players from outside the sample of the standard model and (12) students from outside the basic research sample, in order to find scientific transactions (belief - stability) for the two tests used in the 
research, and to confirm the validity of the performance The value of the $\mathrm{T}$ measurement was $3.55,3.75$, which is greater than the value of the $\mathrm{T}$ scale at a moral level of 0.05 and free grades of $11=2.2$ and the value of the correlation coefficient for the two tests was $0.987,0.975$ greater than the value of the "R" table at the significance level of 0.05 and the $10=0.576$ free degrees.

The basic study of the standard model:

The two researchers conducted the basic experiment on Thursday, $16 / 2 / 2018$ at 2:00 p.m. at faculty of girls physical education zagazig university the cameras was placed whereas distance between the first camera from the player (5) Meters, camera height from ground (90)CM with an angle (90) degrees in front of the player and placed the second camera at the same distance and height but on the right side of the front and the angle of the camera with a $\left(45^{\circ}\right)$ angle the third camera was placed in the same setting but on the left side of the front and at an angle of $\left(45^{\circ}\right)$, and the fourth camera was placed in the same setting but on the right side from the back and at an angle of $\left(45^{\circ}\right)$, the fifth camera was placed in the same setting as the fourth camera but on the left side of the rear and at an angle $\left(45^{\circ}\right)$, during the performance of the skills in question, the camera speed was adjusted to 250 frames/s, where the cameras operate with a unified electronic synchronization system through the unit Remote control that is set up and calibrated.

\section{Educational program:}

\section{The objectives of the tutorial:}

In light of the objective of the research and its questions and the results of the 3D kinematic imaging of the two skills of the straight vertical blow and hit the ball with the flat face and the differences between them was determined the goal of the educational program in teaching the skill of hitting the ball with the flat face according to some kinematic indicators

\section{Determining the content of the program:}

The content of the educational program for this study has been to teach the skill of hitting the ball with the flat face according to some 
kinematic indicators derived from the three-dimensional kinematic imaging of the two skills of the straight vertical blow and hitting the ball with the flat face and the differences between them to teach the skill of hitting the ball With a flat face.

Timeline for implementing the program:

include (4) weeks by one educational unit per week, and the time of the educational unit was (90) minutes and the daily unit contains administrative work, (5m) warm-up, $(5 \mathrm{~m})$ warming up, $(70 \mathrm{~m})$ main part, $(5 \mathrm{~m})$ closing. The executive steps of the search experience: Pre measurement:
Pre measurements were conducted in the ball-hitting accuracy test on the experimental research group on Saturday, 31 March 2018.

Basic experiment:

The educational program applied to the experimental group, from Tuesday, April 3, to Tuesday, April 24, 2018.

\section{Post measurement:}

on Thursday, April 26, 2018.

\section{Statistical treatments}

Mean - Median - Standard Deviation - correlation -

Skewness - t-test - regression presentation and discussion of results:

First: Presenting and discussing the results of the first question:

Table (1)

The highest correlation factors matrix is a correlation between the kinematic variables and the Performance accuracy level for straight vertical hitting skill and hitting the ball with the flat face during the moment of back swinging and hitting moment

\begin{tabular}{|c|c|c|c|c|c|c|}
\hline Moment & Indicator name & $\begin{array}{c}\text { Measurement } \\
\text { unit }\end{array}$ & $\begin{array}{c}\text { Mean } \\
\text { deviation }\end{array}$ & $\begin{array}{l}\text { Standard } \\
\text { deviation }\end{array}$ & $\begin{array}{c}\text { Correlation } \\
\text { coefficient }\end{array}$ & $\begin{array}{l}\text { Index } \\
\text { order }\end{array}$ \\
\hline \multirow{8}{*}{ 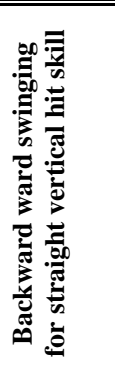 } & $\begin{array}{l}\text { Horizontal displacement of } \\
\text { the racket }\end{array}$ & $\mathrm{M}$ & -0.349 & 0.365 & 0.960 & first \\
\hline & $\begin{array}{l}\text { Transverse displacement of } \\
\text { the racket }\end{array}$ & M & 0.364 & 0.648 & 0.940 & second \\
\hline & $\begin{array}{l}\text { Vertical displacement } \\
\text { of the right trunk }\end{array}$ & $\mathrm{M}$ & 0.903 & 0.084 & 0.960 & third \\
\hline & $\begin{array}{l}\text { Vertical velocity of } \\
\text { the right elbow }\end{array}$ & $\mathrm{M} / \mathrm{S}$ & -2.229 & 0.124 & 0.940 & fourth \\
\hline & $\begin{array}{l}\text { Vertical displacement } \\
\text { of the left trunk }\end{array}$ & $\mathrm{M}$ & 0.894 & 0.068 & -0.891 & Fifth \\
\hline & $\begin{array}{l}\text { The transverse velocity of } \\
\text { the right foot }\end{array}$ & $\mathrm{M} / \mathrm{S}$ & -0.717 & 0.739 & -0.827 & sixth \\
\hline & $\begin{array}{l}\text { The transverse velocity of } \\
\text { the right foot }\end{array}$ & $\mathrm{M} / \mathrm{S}$ & -1.428 & 1.543 & 0.821 & Seventh \\
\hline & $\begin{array}{l}\text { Horizontal velocity of } \\
\text { right foot instep }\end{array}$ & $\mathrm{M} / \mathrm{S}$ & 0.614 & 0.615 & -0.796 & eighth \\
\hline
\end{tabular}


Follow Table (1)

The highest correlation factors matrix is a correlation between the kinematic variables and the Performance accuracy level for straight vertical hitting skill and hitting the ball with the flat face during the moment of back swinging and hitting moment

\begin{tabular}{|c|c|c|c|c|c|c|}
\hline Moment & Indicator name & $\begin{array}{c}\text { Measurement } \\
\text { unit }\end{array}$ & $\begin{array}{c}\text { Mean } \\
\text { deviation }\end{array}$ & $\begin{array}{l}\text { Standard } \\
\text { deviation }\end{array}$ & $\begin{array}{c}\text { Correlation } \\
\text { coefficient }\end{array}$ & $\begin{array}{l}\text { Index } \\
\text { order }\end{array}$ \\
\hline & $\begin{array}{l}\begin{array}{l}\text { Horizontal displacement of } \\
\text { the left shoulder }\end{array}\end{array}$ & $\mathrm{M}$ & 0.697 & 0.104 & 0.784 & Ninth \\
\hline & $\begin{array}{l}\text { Vertical displacement } \\
\text { of the right shoulder }\end{array}$ & $\mathrm{M}$ & 1.086 & 0.709 & -0.718 & tenth \\
\hline \multirow{10}{*}{ 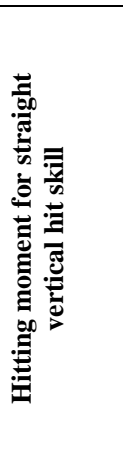 } & $\begin{array}{l}\text { Vertical displacement } \\
\text { of the left trunk }\end{array}$ & M & 0.881 & 0.090 & -0.858 & first \\
\hline & $\begin{array}{l}\text { Horizontal velocity of } \\
\text { the ball }\end{array}$ & $\mathrm{M} / \mathrm{S}$ & 4.061 & 3.29 & 0.753 & second \\
\hline & $\begin{array}{l}\text { The transverse velocity of } \\
\text { the left shoulder }\end{array}$ & $\mathrm{M} / \mathrm{S}$ & 8.761 & 6.06 & -0.748 & third \\
\hline & $\begin{array}{l}\text { Transverseting of the } \\
\text { left shoulder }\end{array}$ & $\mathrm{M}$ & 1.031 & 0.427 & -0.724 & fourth \\
\hline & $\begin{array}{l}\text { Vertical displacement } \\
\text { of the right elbow }\end{array}$ & M & 0.704 & 0.061 & -0.718 & Fifth \\
\hline & $\begin{array}{l}\text { The vertical velocity } \\
\text { of the right shoulder }\end{array}$ & $\mathrm{M} / \mathrm{S}$ & 0.997 & 0.092 & -0.717 & sixth \\
\hline & $\begin{array}{l}\text { Horizontal displacement of } \\
\text { the right shoulder }\end{array}$ & $\mathrm{M}$ & 0.633 & 0.163 & 0.715 & Seventh \\
\hline & $\begin{array}{l}\text { Vertical displacement } \\
\text { of the right elbow }\end{array}$ & M & 0.704 & 0.612 & -0.712 & eighth \\
\hline & $\begin{array}{l}\text { Horizontal velocity of } \\
\text { the ball }\end{array}$ & $\mathrm{M} / \mathrm{S}$ & 4.061 & 3.297 & 0.710 & Ninth \\
\hline & Vertical speed of the head & $\mathrm{M} / \mathrm{S}$ & -0.165 & 0.519 & -0.709 & tenth \\
\hline \multirow{10}{*}{ 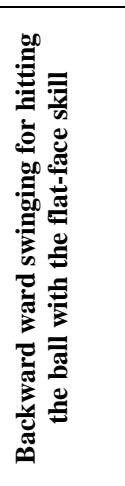 } & $\begin{array}{l}\text { Vertical displacement } \\
\text { of the left trunk }\end{array}$ & $\mathrm{M}$ & 0.918 & 0.091 & -0.893 & first \\
\hline & $\begin{array}{l}\text { Horizontal displacement of } \\
\text { the racket }\end{array}$ & $\mathrm{M}$ & -0.372 & 0.725 & 0.853 & second \\
\hline & $\begin{array}{l}\text { Vertical displacement } \\
\text { of the right trunk }\end{array}$ & M & 0.926 & 0.088 & -0.821 & third \\
\hline & $\begin{array}{l}\text { Vertical velocity of } \\
\text { the right elbow }\end{array}$ & $\mathrm{M} / \mathrm{S}$ & -1.734 & 1.246 & -0.769 & fourth \\
\hline & $\begin{array}{l}\text { Transverse displacement of } \\
\text { the racket }\end{array}$ & $\mathrm{M}$ & 1.04 & 0.946 & 0.762 & Fifth \\
\hline & $\begin{array}{l}\text { Vertical displacement } \\
\text { of the right foot }\end{array}$ & $\mathrm{M}$ & 0.046 & 0.041 & 0.761 & sixth \\
\hline & $\begin{array}{l}\text { Vertical displacement } \\
\text { of the right foot instep }\end{array}$ & $\mathrm{M}$ & 0.029 & 0.173 & 0.753 & Seventh \\
\hline & $\begin{array}{l}\text { The right velocity of } \\
\text { the left foot }\end{array}$ & $\mathrm{M} / \mathrm{S}$ & 0.56 & 0.111 & 0.737 & eighth \\
\hline & $\begin{array}{l}\text { Parallel displacement } \\
\text { of the right foot }\end{array}$ & M & 0.99 & 0.155 & -0.724 & Ninth \\
\hline & $\begin{array}{l}\text { The left velocity of the } \\
\text { left wrist }\end{array}$ & $\mathrm{M} / \mathrm{S}$ & 3.707 & 2.435 & 0.709 & tenth \\
\hline \multirow{6}{*}{ 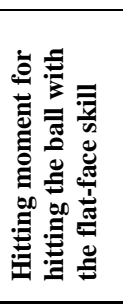 } & $\begin{array}{l}\text { The transverse velocity of } \\
\text { the left shoulder }\end{array}$ & $\mathrm{M} / \mathrm{S}$ & 5.867 & 5.99 & -0.781 & first \\
\hline & $\begin{array}{l}\text { Vertical displacement } \\
\text { of the right elbow }\end{array}$ & $\mathrm{M}$ & 2.983 & 3.29 & 0.771 & second \\
\hline & $\begin{array}{l}\text { Vertical displacement } \\
\text { of the left trunk }\end{array}$ & $\mathrm{M}$ & 1.01 & 0.194 & -0.734 & third \\
\hline & $\begin{array}{l}\text { Transverseting of the } \\
\text { left shoulder }\end{array}$ & $M$ & 1.026 & 0.227 & -0.709 & fourth \\
\hline & $\begin{array}{l}\text { Horizontal velocity of } \\
\text { the ball }\end{array}$ & $\mathrm{M} / \mathrm{S}$ & 4.68 & 3.792 & 0.708 & Fifth \\
\hline & $\begin{array}{l}\text { Vertical displacement } \\
\text { of the shoulder }\end{array}$ & $\mathrm{M}$ & 1.349 & 0.363 & -0.707 & sixth \\
\hline \multicolumn{3}{|c|}{$\begin{array}{l}\text { Table } \mathrm{r} \text { value at a moral } \\
\text { level of } 0.05 \text { and free grades of } \\
6=0.707\end{array}$} & (1) & \multicolumn{3}{|c|}{$\begin{array}{l}\text { It is clear from the table } \\
\text { the higher kinematic }\end{array}$} \\
\hline & \multicolumn{3}{|c|}{ Assiut Journal For Sport Science Arts } & & & \\
\hline
\end{tabular}


variables related to the level of performance accuracy of the skill of the straight vertical blow and hitting the ball with the flat face during the moment of back swinging and hitting moment

Thus, the first question was answered: "Is there a correlation between the

Table (2)

Contribution ratio of kinematic indicators in the performance accuracy level of straight vertical stroke skill And hit the ball with the flat face During the moment of back swinging and hitting moment

\begin{tabular}{|c|c|c|c|c|c|c|c|c|c|c|c|}
\hline Moments & $\begin{array}{l}\text { Kinematic } \\
\text { indicators }\end{array}$ & $\begin{array}{c}\text { Mean } \\
\text { deviation }\end{array}$ & $\begin{array}{c}\text { Fixed } \\
\text { amount }\end{array}$ & $\begin{array}{c}\text { Standard } \\
\text { error }\end{array}$ & $\begin{array}{c}\text { "f" } \\
\text { value }\end{array}$ & \multicolumn{5}{|c|}{ Regression coefficient } & $\begin{array}{c}\text { Contribution } \\
\text { Ratio }\end{array}$ \\
\hline \multirow{5}{*}{ 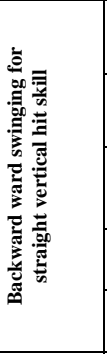 } & $\begin{array}{l}\text { Horizontal } \\
\text { displacement } \\
\text { of the racket }\end{array}$ & -0.350 & 2.349 & 3.670 & 1.871 & -3.900 & & & & & 63.774 \\
\hline & $\begin{array}{l}\text { Transverse } \\
\text { displacement } \\
\text { of the racket }\end{array}$ & .0364 & 0.181 & 1.100 & 41.334 & -5.166 & 4.740 & & & & 94.297 \\
\hline & $\begin{array}{l}\text { Vertical } \\
\text { displacement } \\
\text { of the right } \\
\text { trunk }\end{array}$ & 0.904 & 0.010 & 0.503 & 138.545 & 2.751 & 0.899 & 4.803 & & & 99.047 \\
\hline & $\begin{array}{l}\text { Vertical } \\
\text { velocity of the } \\
\text { right elbow }\end{array}$ & -2.230 & 0.008 & 0.307 & 279.839 & 2.344 & 0.388 & 3.709 & $\begin{array}{c}- \\
0.464\end{array}$ & & 99.773 \\
\hline & $\begin{array}{l}\text { Vertical } \\
\text { displacement } \\
\text { of the left trunk }\end{array}$ & 0.894 & 0.007 & 0.365 & 158.500 & 2.356 & 0.210 & 1.607 & $\begin{array}{c}- \\
0.528\end{array}$ & 2.045 & 99.748 \\
\hline \multirow{5}{*}{ 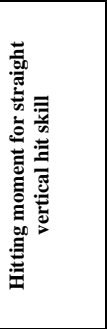 } & $\begin{array}{l}\text { Vertical } \\
\text { displacement } \\
\text { of the left trunk }\end{array}$ & 0.881 & 0.126 & 1.586 & 36.161 & 4.071 & & & & & 85.769 \\
\hline & $\begin{array}{l}\text { Horizontal } \\
\text { velocity of the } \\
\text { ball }\end{array}$ & 4.061 & 0.044 & 1.045 & 46.072 & 2.537 & 0.353 & & & & 94.853 \\
\hline & $\begin{array}{l}\text { The left } \\
\text { velocity of the } \\
\text { left shoulder }\end{array}$ & 8.761 & 0.037 & 0.982 & 35.282 & 3.387 & 0.360 & -0.088 & & & 96.359 \\
\hline & $\begin{array}{l}\text { Transverse } \\
\text { velocity of the } \\
\text { left shoulder }\end{array}$ & 1.031 & 0.037 & 1.085 & 21.741 & 2.964 & 0.292 & -0.158 & 1.225 & & 96.665 \\
\hline & $\begin{array}{l}\text { Vertical } \\
\text { displacement } \\
\text { of the right } \\
\text { elbow }\end{array}$ & 0.704 & 0.030 & 1.237 & 13.453 & -3.933 & 0.277 & -0.141 & 0.514 & 9.566 & 97.113 \\
\hline \multirow{5}{*}{ 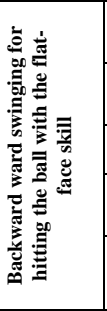 } & $\begin{array}{l}\text { Vertical } \\
\text { displacement } \\
\text { of the left trunk }\end{array}$ & 0.918 & 0.097 & 1.192 & 93.164 & 4.717 & & & & & 93.949 \\
\hline & $\begin{array}{l}\text { Horizontal } \\
\text { displacement } \\
\text { of the racket }\end{array}$ & -0.372 & 0.014 & 0.574 & 211.35 & 4.233 & 1.417 & & & & 98.831 \\
\hline & $\begin{array}{l}\text { Vertical } \\
\text { displacement of the } \\
\text { right trunk }\end{array}$ & 0.926 & 0.007 & 0.547 & 155.72 & 17.289 & 1.680 & 13.049 & & & 99.151 \\
\hline & $\begin{array}{l}\text { Vertical } \\
\text { velocity of the } \\
\text { right elbow }\end{array}$ & -1.734 & 0.001 & 0.503 & 138.39 & 15.360 & 1.221 & $11 . \overline{513}$ & $0 . \overline{303}$ & & 99.461 \\
\hline & $\begin{array}{l}\text { Transverse } \\
\text { displacement } \\
\text { of the racket }\end{array}$ & 1.040 & 0.001 & 0.370 & 205.09 & 40.877 & $\overline{-}$ & 38.552 & 0.504 & 2.032 & 99.805 \\
\hline$\pm . \equiv . \equiv$ & $\begin{array}{l}\text { The transverse } \\
\text { velocity of the } \\
\text { left Shoulder }\end{array}$ & 5.867 & 2.302 & 3.675 & 4.439 & 0.362 & & & & & 62.522 \\
\hline
\end{tabular}

kinematic indicators of straight vertical strike skills and hitting the ball with the flat face during the moment of back swinging and hitting moment and performance accuracy?"

Second: Presenting and discussing the results of the second question: 
Follow Table (2)

Contribution ratio of kinematic indicators in the performance accuracy

level of straight vertical stroke skill And hit the ball with the flat face

During the moment of back swinging and hitting moment

\begin{tabular}{|c|c|c|c|c|c|c|c|c|c|c|c|}
\hline \multirow{5}{*}{ Moments } & \multirow{2}{*}{$\begin{array}{l}\begin{array}{l}\text { Kinematic } \\
\text { indicators }\end{array} \\
\text { Vertical } \\
\text { displacement } \\
\text { of the right } \\
\text { elbow }\end{array}$} & \multirow{2}{*}{$\begin{array}{c}\begin{array}{c}\text { Mean } \\
\text { deviation }\end{array} \\
2.289\end{array}$} & \multirow{2}{*}{$\begin{array}{c}\begin{array}{c}\text { Fixed } \\
\text { amount }\end{array} \\
1.154\end{array}$} & \multirow{2}{*}{$\begin{array}{c}\begin{array}{c}\text { Standard } \\
\text { error }\end{array} \\
2.898\end{array}$} & \multirow{2}{*}{$\begin{array}{c}\begin{array}{c}\text { "f" } \\
\text { value }\end{array} \\
5.897\end{array}$} & \multicolumn{5}{|c|}{ Regression coefficient } & $\begin{array}{c}\text { Contribution } \\
\text { Ratio }\end{array}$ \\
\hline & & & & & & 0.313 & 0.628 & \multirow[b]{2}{*}{4.079} & & & 70.228 \\
\hline & $\begin{array}{l}\text { Vertical } \\
\text { displacement } \\
\text { of the left trunk }\end{array}$ & 1.010 & 0.192 & 1.683 & 15.252 & 0.008 & 0.029 & & & & 91.961 \\
\hline & $\begin{array}{l}\text { Transverse } \\
\text { displacement } \\
\text { of the left } \\
\text { shoulder }\end{array}$ & 1.026 & 0.190 & 1.942 & 8.598 & 0.024 & 0.037 & 4.614 & $\begin{array}{c}- \\
0.629\end{array}$ & & 91.977 \\
\hline & $\begin{array}{l}\text { Horizontal } \\
\text { velocity of the } \\
\text { ball }\end{array}$ & 4.680 & .165 & 2.238 & 5.229 & -0.259 & 0.066 & 3.421 & 4.099 & 0.434 & 92.894 \\
\hline
\end{tabular}

It is clear from the table

(2) the contribution ratio of the kinematic indicators in the performance accuracy level of the straight vertical hit skill and hitting the ball with the flat face during the moment of back swinging and hitting moment?

Thus, the second it be possible to recognize the contribution ratios of the kinematic indicators of the straight vertical strike skills and to hit the ball with the flat face at the level of performance accuracy during my weighted retrograde and batting moments?" question was answered: "Can

Table (3)

\begin{tabular}{|c|c|c|c|c|c|c|}
\hline \multirow[b]{2}{*}{ Moment } & \multirow[b]{2}{*}{ Research Variables } & \multicolumn{2}{|c|}{ Ball-hitting strike } & \multicolumn{2}{|c|}{ Straight vertical strike skill } & \multirow{2}{*}{$\begin{array}{c}\text { "T" value } \\
\text { and } \\
\text { significance }\end{array}$} \\
\hline & & $\begin{array}{c}\text { Mean } \\
\text { Deviation }\end{array}$ & $\begin{array}{l}\text { Standard } \\
\text { Deviation }\end{array}$ & $\begin{array}{c}\text { Mean } \\
\text { Deviation }\end{array}$ & $\begin{array}{l}\text { Standard } \\
\text { Deviation }\end{array}$ & \\
\hline \multirow{5}{*}{ 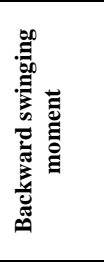 } & $\begin{array}{l}\text { Horizontal displacement of the } \\
\text { bat }\end{array}$ & $\cdot r V Y_{-}$ & $\because$ VYO & $\because r \leq q$ & .470 & *Y.ro \\
\hline & Offset displacement of the bat & $1 . \cdot \varepsilon$ & $\because .9 \leqslant 0$ & $.47 \varepsilon$ & $.7 \leqslant 1$ & $* Y .07$ \\
\hline & $\begin{array}{l}\text { Vertical displacement of the } \\
\text { right trunk }\end{array}$ & .947 & $\because \wedge \lambda$ & $\because .9 \cdot r$ & $\because \wedge \varepsilon$ & $\because \leqslant \vee q$ \\
\hline & $\begin{array}{l}\text { Vertical velocity of the right } \\
\text { elbow }\end{array}$ & r.ITr- & .019 & r.r.q- & $1.1 Y \varepsilon$ & $* r .99$ \\
\hline & $\begin{array}{l}\text { Vertical displacement of the left } \\
\text { trunk }\end{array}$ & 1.91 & $.91 \leqslant$ & $\because \wedge 9 \leqslant$ & $\because \cdot 79$ & .071 \\
\hline \multirow{5}{*}{ 最 } & Horizontal velocity of the ball & ะ.7V9 & $.1 \% \mathrm{~V}$ & $\because \wedge \wedge 1$ & $\because .9$. & $* r . V$ \\
\hline & $\begin{array}{l}\text { The transverse velocity of the } \\
\text { left shoulder }\end{array}$ & $0 . \wedge T V$ & $.1 / 71$ & $\{.71$ & $\cdot V \wedge T$ & $* r . \leqslant 9$ \\
\hline & Offsetting of the left shoulder & 1.97 & I. .71 & $\Lambda . V 7$ & 9.97 & $* Y . \wedge \leqslant 7$ \\
\hline & $\begin{array}{l}\text { Vertical displacement of the } \\
\text { right elbow }\end{array}$ &.$\wedge 9 \%$ & $\because K Y V$ & 1.41 & $\cdot \because Y V$ & $\because \cdot r$ \\
\hline & Accuracy correction & 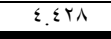 & $0.1 \leqslant 7$ & $\because v \cdot \varepsilon$ & $\because .71$ & *ץ. \\
\hline
\end{tabular}

Table value at 0.05 and free grades score $12=2.178$

Assiut Journal For Sport Science Arts 


\section{4}

The results of table (3) showed that there are statistically significant differences for horizontal and occasional displacements of the racket in the skills of the straight vertical blow and hit the ball with the flat face During the moment of back swinging and in favor of the skill of hitting the ball with the flat face, Where the values of averages are lower in the skill of straight vertical strike than in the skill of hitting the ball in the flat face, as the movement of the racquet and speed is an important indicator of the movement of the dynamic transfer from the racket to the ball as quickly as required and directed to the goal to be reached by increasing the speed of the racket, the researchers think that this is due to The skill of hitting the ball in the flat face requires greater distance and displacement, and the greater time of the backward swinging moment to give the ball more speed. However the straight vertical stroke is faster and therefore the displacement is less.

This is consistent with what Mohamed Abdel Hamid Hassan (2012) (9) stated that the preliminary stage may be the opposite of the direction of the basic movement. This occurs when the movement is a circle around a fixed axis. The preliminary stage of the movement is backward swinging opposite of the direction of the main part Of the movement, and the function of the preliminary stage in this case is to place the center of the weight of the body in the highest energy status (9: 72)

It is clear from the same table that there are statistical significance differences between the vertical velocity of the right elbow in the skills of vertical straight strike and hitting the ball in with the flat face during the back swinging moment and in favor of the straight vertical strike, and the two researchers think that is due to that the skill of hitting the ball with the flat face occurs by a larger extension of the right elbow The straight vertical strike skill, which leads to greater velocity and strength of the ball, produces a longer distance in the strike skill. The lower extension of the right elbow results in a faster clearance of the ball in the straight vertical strike skill. 
And the transfer of dynamic transfer from the trunk to the right hand and where excess speed adversely affects the element of accuracy, and this is consistent with Mohamed Abdel Hamid Hassan, Mahmoud Metwally Bandari (2013) (11) that the movement of the trunk to the limbs It is clearly shown in movements that require fast and strong movement in the limbs such as boxing, karate, crushing skill, and field hockey (11: 93)

The results of Table (3) showed that there are statistically significant differences for the vertical displacement of the left trunk in the vertical and straight ball strikes during the moment of hitting and in favor of the skill of hitting the ball with the flat face. The mean values were lower in the straight vertical strike skill The left side of the left torso in hitting is the knee of the back foot (north) is almost fully extended, and there is a slight flexion in the front foot, giving a greater preference for the movement of the trunk in the skill of hitting the ball with the flat face than the skill of beating Vertical straight, but in the skill of the straight vertical strike there is bending in the knees of frontal and back of the, and this is in line with the nature of the skill.

As shown by the same table that there are differences of statistical significance of the horizontal speed of the ball in the skills of vertical strike straight and hit the ball flat face during the moment of beating and in favor of the skill of hitting the ball flat face, and the two researchers that the more the ball moved in the direction of the target more quickly, The braking movement of the hand, elbow, and left shoulder at the moment of collision with the ball serves to guide the ball to the desired goal. The lower the speed of the striking arm, the more accurate the ball is. The result of the strike is based on the speed of the stick, the correct timing when hitting the ball after finishing the weighted process of the bat, and the use of the force of the arms, arms and trunk. (3: 32)

While it is clear from the same table that there are statistically significant differences of the lateral velocity of the left shoulder in the skills of vertical strike 
straight and hit the ball flat face during the moment of beating and in favor of the vertical strike straight, and the two researchers that the movement of the shoulders is similar to the lever of the second type, The left shoulder and the resistance are the extension of the shoulder blades to the right shoulder and the arm is the force arm. For faster weighted production, one of the joints must be installed and the last joint should be left free according to the open kinetic chain. The movement comes from damping or breaking that takes place in the remote part The left movement of the left joint leads to the determination of the path of the ball. The base of the movement of the injury comes from the left joint, which is the left shoulder joint. The lower the speed of the joint, the greater the relative movement of the joint, The base rule is on the edge of performance and resistance in the center and force at the end of the kinetic chain.

The researchers attribute that to the fact that the skill of the straight vertical strike is a quick skill while the skill of hitting the ball with the flat face is a skill that produces a ball that is characterized by the speed and strength that enables it to move long distances in the stadium in length and width.

This is consistent with Mohammed Abdul Hamid Hassan, Mohammed Abdul Wahab Badri (2014) (12) that the athletic movement increases if it was accompanied with swinging movement of the arms or the legs and this why the end of the kinematic chain of the human movement instrument (the hand) gain lots of speed to be able to push or throw a foreign object such as a roll, spear or ball. (12: 53, 54)

This result is also consistent with what Ayman al-Bassiti, Muhammad Ahmad Abdullah (2000) (3), noted that the left hand holds the racket and the right is adjacent to it to increase the force applied which leads to a powerful and swift performance. (3: 32)

It is also clear from the same table that there are statistically significant differences of the vertical displacement of the right elbow in the vertical strike and the ball hit with the flat face during 
the moment of hitting and for the skill of hitting the ball with the flat face, and the two researchers Attribute that to the different methods of racket handling performance in the two skills under consideration, Where in the skill of the straight vertical strike there is a distance between the right fist and the left fist, so the right elbow during the moment of striking closer to the ground where the height of the ball from the ground about $5 \mathrm{~cm}$, so it must match the ball height, so The right and left hand grips are adjacent at the upper end of the racket, thus the right elbow moves away from the ground during the hitting moment

While it is clear from the same table that there are differences of statistical significance in the accuracy of aiming in the skills of the straight vertical strike and hitting the ball with flat face during the moment of hitting and in favor of the skill of hitting the ball, and the two researchers attribute that the more time it takes the more accurate it is, as the role of angular steering of the wrist which is responsible for steering the ball has more influence in the skill of hitting the ball with the flat face than the skill of straight vertical strike, and since there is an inverse relationship between speed and accuracy, the lower the speed the higher accuracy, and therefore the accuracy is greater in the skill of hitting the ball with the flat face than the skill of straight vertical strike, this is consistent with what Jalal al-Din (2005) (1) pointed, that,in order to perform the motor duties that require both precision and speed at the same time successfully, it is the more important to have a high level of accuracy at the expense of speed at specified rates. (1:18)

This result is consistent with what Ayman al-Basiti, Muhammad Ahmad Abdullah (2000) (3), pointed out, that the skill of striking the ball is one of the most skills that require aiming on the goal because it has speed and accuracy thus it is difficult for the goal keeper to deal with it $(1: 32)$

Thus, the third question was answered: "Are there kinematic differences between the skills of the straight vertical strike and the ball hitting the flat face and the level of accuracy of performance 
during the moments of IV. Presentation and backward swinging and hitting for the most saturated discussion of the results of connections?" the fourth question:

Table (4)

The significance of the differences between the pre and post measurements of the experimental group $n=20$

\begin{tabular}{|c|c|c|c|c|c|c|c|}
\hline \multirow[t]{2}{*}{ Variables } & \multirow{2}{*}{$\begin{array}{c}\text { measruing } \\
\text { unit }\end{array}$} & \multicolumn{2}{|c|}{$\begin{array}{c}\text { Post- } \\
\text { measurement }\end{array}$} & \multicolumn{2}{|c|}{$\begin{array}{c}\text { Pre - } \\
\text { measurement }\end{array}$} & \multirow{2}{*}{$\begin{array}{l}\text { Value } \\
\text { (T) }\end{array}$} & \multirow{2}{*}{$\begin{array}{c}\text { Percentage } \\
\text { improvement }\end{array}$} \\
\hline & & $r S$ & $\mathbf{r A}$ & IS & $1 \mathrm{~A}$ & & \\
\hline $\begin{array}{l}\text { Test the } \\
\text { accuracy of } \\
\text { hitting the } \\
\text { ball with the } \\
\text { flat face }\end{array}$ & Number & $1.7 \varepsilon$ & r.91 & $1 . \mathrm{VA}$ & $1 . r$ & $* \varepsilon .11$ & INr.or \\
\hline
\end{tabular}

T Table value at 0.05 and free grades score $19=2.093$

statistically significant at 0.05 level

The results of Table (4)

Shows statistically significant differences at level 0.05 between the pre and post measurements of the experimental group in the skill of hitting the ball with the flat face in favor of the post measurement. The two studies attributed this to the fact that the educational program which was prepared based on the kinetic comparison between the skills of the straight vertical strike and the ball hitting with the flat face and the results obtained from this comparison, which resulted in the identification of the most kinetic indicators associated with the accuracy of the skillful performance of the skill of hitting the ball with the flat face, The possibility of building qualitative exercises to teach the skill of hitting the ball with the flat face in accordance with the movement path of the skill performance, which led to the educational program having a more positive and more effective effect in teaching skill.

This result is also consistent with the studies of Israa Osama Muhammad Khalil Ahmad (2017)(6), Muhammad Ahmed Mahmoud Bader (2011)(14), Mohamed Abdel Hamid Hassan Ali, 
Tariq Gamal Mohamed Alaeddin (2015) (10) Training and education programs based on the results of biomechanical and kinetic analysis will have a positive effect on the education and training of various sports skills.

\section{The answer to the} fourth question, which states: "Are there statistically significant differences between the pre and post measurements of the experimental group in the post measurement of the skill of hitting the ball with the flat face of the students of the first division of the Faculty of Physical Education for Girls Zagazig University?

\section{Conclusions}

and

\section{Recommendations:}

First: Conclusions

In light of the objectives of the research and the sample, and the following procedures, the researchers concluded the following:

The skill of hitting the ball with the flat face is more accurate than the straight vertical strike skill. The speed of the left shoulder should be reduced during the moment of hitting. The educational program has a positive effect on learning the skill of hitting the ball with the flat face.

\section{Second: Recommendations:}

Using the results of kinetic analysis in developing educational programs for different groups. Guided by the values of the biomechanical indicators reached to determine the efficiency of the skill performance of the straight vertical strike and the ball hitting the flat face in the field hockey sport.

\section{References:}

1- Ali Jalal al-Din (2005): accuracy, the book center for publishing, Cairo.

\section{2- AnthonyBlazevich(2007) :}

Sports Biomechanics Bio Michanics The Basics. Optimising Human Perfomance: A\&C Blak Publishers Ltd 38 Soho Square,London WID3HB ISBN.
3-
Ayman
Al-Basiti,
Muhammad
Ahmad 
Abdullah (2000): theoretical and applicaple field hockey and, unpublished memoirs, Faculty of Physical Education for Boys, Zagazig University.

4- Claire Mitchell \& Verner (2005): Field Hockey Techniques \& Tactics, Human Kinetice.

5- Eileen Wadie (2008): filed hockey, Scientific and Training Foundations, Al-Ma'aref Establishment, Alexandria.

6- Esraa Osama Mohamed Khalil Ahmed (2017): Effect of ballistic training on the development of some physical, skill and biomechanical variables of the field hockey players, Faculty of Physical Education for Girls, Zagazig University.

7- Kamal Abdel-Hamid Ismail (2011): the theory of racket sports and it's applications, the book center for publishing, Egypt.

8- Less Adrian (2003):

Science and the major racket sports: a Review Journal of sports Sciences.

\section{9- Mohamed Abdel Hamid} Hassan (2012): Applications and theories of motion science in collective sports, Zagazig University Press, Zagazig.

10- Mohamed Abdel Hamid Hassan Ali, Tariq Gamal Mohamed Alaa Eddin (2015): Using an innovative method to control the rotation of the basin to improve the speed of performance of the skill of hitting fast with the flat face in field hockey, research published in the scientific journal of physical education and sports Faculty of Physical Education for Girls University of Alexandria.

\section{1- Mohamed Abdel Hamid} Hassan, Mahmoud Metwally Bendari (2013): Methodology of applications of motion science in the field of sports, Zahra library, Zagazig.

\section{2- Mohamed Abdel Hamid} Hassan, Mohamed Abdel Wahab Badry (2014): Applications of biomechanics in the field of sports, Zahra library, Zagazig. 
13- Mohammed Ahmed Abdullah Ibrahim (2006): Comprehensive preparation for hockey players, Ayat Center for Printing and Computer, Egypt.

\section{4- Mohammed Ahmed} Mahmoud Badr (2011):

Effect of a program on ballistic training on maximum muscle capacity and some mechanical properties for the penalty corner strike aiming in the field hockey, unpublished $\mathrm{PhD}$ thesis, Faculty of Physical
Education Boys, Zagazig University.

15- Roger Bartlett (2007): Introduction to Sports Biomechanics Analyzing Human Movement Ptterns :,Routledge London and new York ， ISBN 0-203-46202-5 Master e-book ISBN.

16- Talha Hossam El-Din and others (2014): The ABCs of Movement Science - The Biomechanical Approach in Movement Science Studies, The Modern Book Center, Cairo. 